\title{
Productive Infection of Isolated Human Alveolar Macrophages by Respiratory Syncytial Virus
}

\author{
James R. Panuska, ${ }^{*}$ Nick M. Cirino, ${ }^{*}$ Fabio Midulla, ${ }^{*}$ Janet E. Despot, ${ }^{*}$ E. R. McFadden, Jr., and Yung T. Huang \\ Airway Disease Center and Departments of ${ }^{*}$ Medicine and ${ }^{\ddagger}$ Pathology, University Hospitals \\ of Case Western Reserve University, Cleveland, Ohio 44106
}

\begin{abstract}
Respiratory syncytial virus (RSV) is a significant cause of lower respiratory tract disease in children and individuals with cell-mediated immunodeficiencies. Airway epithelial cells may be infected with RSV, but it is unknown whether other cells within the lung permit viral replication. We studied whether human alveolar macrophages supported RSV replication in vitro. Alveolar macrophages exposed to RSV demonstrated expression of RSV fusion gene, which increased in a time-dependent manner and correlated with RSV protein expression. RSV-exposed alveolar macrophages produced and released infectious virus into supernatants for at least $25 \mathrm{~d}$ after infection. Viral production per alveolar macrophage declined from 0.053 plaque-forming units (pfu)/cell at $24 \mathrm{~h}$ after infection to 0.003 pfu/cell by $10 \mathrm{~d}$ after infection and then gradually increased. The capability of alveolar macrophages to support prolonged RSV replication may have a role in the pulmonary response to RSV infection. (J. Clin. Invest. 1990.86:113-119.) Key words: mononuclear phagocyte $\bullet$ viral replication $\bullet$ fusion gene $\bullet$ respiratory virus $\bullet$ long-term cultures
\end{abstract}

\section{Introduction}

Respiratory syncytial virus (RSV) ${ }^{1}$ is a major cause of childhood bronchiolitis and pneumonia and demonstrates peculiar tropism for the lower respiratory tract of young children (1). RSV may induce an airway inflammatory response (2) as seen in pathological studies, which have demonstrated RSV antigen-expressing cells in alveolar lumina $(3,4)$ and increases in lymphocytes and mononuclear phagocytes (MP) in lung specimens from children with RSV-induced bronchiolitis $(5,6)$. Although tracheal epithelial cells are permissive to RSV infec-

This work was presented in abstract form at the Annual Meeting of the American Thoracic Society, Cincinnati, OH, May 1989.

Dr. Midulla's present address is IV Cattedra di Clinica Pediatrica, University of Rome "La Sapienza," Rome, Italy.

Address correspondence to Dr. James R. Panuska, Airway Disease Center, University Hospitals, 2074 Abington Road, Cleveland, OH 44106.

Received for publication 20 June 1989 and in revised form 5 March 1990.

1. Abbreviations used in this paper: F, fusion; MP, mononuclear phagocytes; pfu, plaque-forming units; RSV, respiratory syncytial virus.

J. Clin. Invest.

(c) The American Society for Clinical Investigation, Inc.

0021-9738/90/07/0113/07 \$2.00

Volume 86, July 1990, 113-119 tion in vitro (7), little is known about the replication of RSV in other pulmonary cells, particularly those involved in lung defense.

The alveolar macrophage is thought to have a major role in defense of the respiratory tract against invading pathogens, including virus (8-11). Alveolar MP may be exposed to RSV via the airstream or by virus replication within the respiratory tract $(3,9)$. In a previous study, we demonstrated that alveolar and blood MP exposed to RSV in vitro can express viral proteins, indicating that these cells are permissive to RSV infection (12). However, infection may result in distinct outcomes, including latent, abortive, or persistent infections characterized by absent or low levels of release of new virus (13). Viral infection may also result in cytolytic and/or productive infection generally resulting in the release of new progeny virus (14). These separate outcomes of viral infection may have unique consequences for the host. Since the nature of the viral replicative cycle in alveolar MP has potential effects on the pulmonary immune response to RSV, we felt that it was important to determine which of these possible outcomes follows RSV infection of alveolar MP.

RSV infection of alveolar macrophages was studied initially by monitoring the expression of RSV fusion (F) RNA and the expression of viral proteins. The RSV F gene of $1.9 \mathrm{~kb}$ in length is transcribed eight genes downstream from the RSV promotor (15), and F protein is thought to promote intercellular viral spread (16-19). It was further determined whether RSV-infected alveolar MP produced and released infectious virus. The data obtained indicate that human alveolar MP support all stages of the RSV replicative cycle and produce infectious virus for up to $25 \mathrm{~d}$ after infection.

\section{Methods}

Preparation and RSV infection of monocytes and alveolar macrophages. 12 healthy, nonsmoking adult volunteers each underwent venipuncture and bronchoalveolar lavage using standard techniques. Informed consent was obtained from each participant and studies were approved by the institutional review board, University Hospitals of Cleveland. PBMC adherent to plastic petri dishes precoated with $\mathrm{AB}$ sera (Whittaker M. A. Bioproducts, Walkersville, MD) were prepared after Ficoll-Hypaque centrifugation as previously described (20).

Alveolar macrophages were isolated from bronchoalveolar lavage fluid by minor modifications of methods previously described (21). After bronchoscopy, segments of the right middle and lower lobes were lavaged with sterile saline $\left(0.9 \%, 240 \mathrm{ml}, 37^{\circ} \mathrm{C}\right)$ in $60-\mathrm{ml}$ aliquots followed by immediate aspiration. Lavage fluid was centrifuged at 500 $g$ for $10 \mathrm{~min}$, and the cell pellet was washed twice with RPMI-1640 (Gibco Laboratories, Grand Island, NY). Alveolar macrophages were isolated by adherence to plastic precoated with $A B$ sera for $1 \mathrm{~h}$ at $37^{\circ} \mathrm{C}$. Nonadherent cells were removed by washing three times with cold HBSS (Gibco Laboratories). Alveolar and blood MP preparations were $>95 \%$ viable and $>90 \%$ nonspecific esterase positive.

Blood and alveolar MP $\left(5 \times 10^{5}\right.$ cells $\left./ 0.5 \mathrm{ml}\right)$ were allowed to 
adhere to 12-well tissue culture plates (Costar, Cambridge, MA) and then exposed for $2 \mathrm{~h}$ at $37^{\circ} \mathrm{C}$ to Eagle's MEM (Whittaker M. A. Bioproducts) containing 2\% (vol/vol) FCS (Hyclone, Logan, UT) or to this medium containing RSV at a multiplicity of infection of 3 plaque-forming units (pfu)/cell. Cells were then washed once in RPMI without serum and cultured in RPMI containing 10\% (vol/vol) FCS and $2 \mathrm{mM}$ glutamine, $1 \mathrm{mM}$ nonessential amino acids, $100 \mathrm{U} / \mathrm{ml}$ penicillin, $100 \mu \mathrm{g} / \mathrm{ml}$ streptomycin, and $0.25 \mu \mathrm{g} / \mathrm{ml}$ amphotericin B (culture medium) at $37^{\circ} \mathrm{C}$ in $5 \% \mathrm{CO}_{2}$. Culture medium from individual, parallel wells was recovered at 2-, 6-, 24-, and 120-h intervals, and after centrifugation at $500 \mathrm{~g}$ cell-free supernatants were frozen at $-70^{\circ} \mathrm{C}$ for determination of viral titers. Adherent alveolar MP were washed once in culture medium at each time interval and harvested by gentle scraping with a rubber policeman for determination of viability, immunofluorescent staining, and viral titer. Parallel uninfected and infected cultures were washed once and incubated in fresh culture medium at each 5-d interval for the $25 \mathrm{~d}$ of study.

Viability of MP cultures was determined after resuspension of the cells in $0.05 \%$ (wt/vol) trypan blue in PBS and enumeration of the percentage of cells that excluded the dye by light microscopy. In selected experiments, viability of adherent MP cultures was assessed by fluorescent microscopy after staining with acridine orange and ethidium bromide, each dye at $1 \mu \mathrm{g} / \mathrm{ml}$ in PBS, for $1 \mathrm{~min}$. Acridine orange stains the nuclei of viable cells green, while ethidium bromide stains the nuclei of nonviable cells orange (22). The results obtained by these separate assays for viability agreed within $\pm 15 \%$. Latex particle ingestion by MP cultures was performed as previously described (20).

$R S V$ preparation and viral titer. Respiratory syncytial A2 strain virus was propagated in CV-1 cells (African green monkey kidney cell line; American Type Culture Collection, Rockville, MD) in Eagle's MEM as previously described (12). Virus titer was determined by incubation of serial dilutions of virus stocks, cell-free supernatants, or sonicated alveolar MP (15 s twice, sonic dismembrator; Artek Systems Corp., Farmingdale, NY) on CV-1 monolayers, overlayed with $0.5 \%$ (wt/vol) agarose and stained with $2 \%$ (wt/vol) crystal violet in $10 \%$ ( $\mathrm{vol} / \mathrm{vol})$ formalin after $5 \mathrm{~d}$ of incubation. Inactivated virus was prepared by exposure to ultraviolet (UV) light $(15 \mathrm{~W})$ at a distance of 10 $\mathrm{cm}$ for $1 \mathrm{~h}$ or by storage at room temperature for $7 \mathrm{~d}$. Viral titer per cell was determined from total virus in supernatant and disrupted cells divided by the number of viable cells times the percentage of infected cells for each donor at each time point.

Immunofluorescent staining. MP were fixed while plastic adherent with $100 \%$ methanol at $4^{\circ} \mathrm{C}$ for $10 \mathrm{~min}$, or harvested with a rubber policeman, resuspended in $0.075 \mathrm{ml}$ of PBS, and applied to microscope slides $\left(5 \times 10^{3}\right.$ cells/slide), air dried, and fixed with cold acetone for $10 \mathrm{~min}$ at $4^{\circ} \mathrm{C}$. The cells were reacted for $30 \mathrm{~min}$ with either a mixture of mouse MAb to RSV proteins conjugated to FITC (Bartels Immunodiagnostic Supplies Inc., Sacramento, CA) or a monospecific rabbit antibody to $F$ (a kind gift of Samuel Levine, Wayne State University, Detroit, $\mathrm{MI})$ followed by a goat anti-rabbit $\mathrm{F}\left(\mathrm{ab}^{\prime}\right)_{2}$ antibody (rhodamine labeled; Southern Biotechnology Associates, Inc., Birmingham, AL). The cells were washed three times in PBS, dried and mounted with PBS/glycerol (1:1, vol/vol), and analyzed by phase contrast and epi-fluorescent microscopy.

RNA isolation, Northern blot analysis, and whole cell dot blot analysis. RNA was extracted from cellular pellets by published methods (23) using $4 \mathrm{M}$ guanidine isothiocyanate (IBI, New Haven, CT) and centrifugation on a solution of $5.7 \mathrm{M}$ cesium chloride (Sigma Chemical Co., St. Louis, MO) in a rotor (SW 50.1; Beckman Instruments, Inc., Palo Alto, CA) at 36,000 rpm for $16 \mathrm{~h}$. Total RNA, quantitated spectrophotometrically, was electrophoresed through $0.9 \%$ agarose formaldehyde gels, stained with ethidium bromide (Sigma Chemical Co.), and transferred to Genescreen membranes (New England Nuclear, Boston, MA) (23). Size estimation of the RNA transcripts was measured by comparison with a formamide denatured Bst EII lambda digest DNA ladder (New England Biolabs, Beverly, MA). The membranes were baked at $80^{\circ} \mathrm{C}$ for $2 \mathrm{~h}$.

Whole cell RNA dot blots were performed with minor modifica- tions of published techniques (24). Briefly, twofold serial dilutions of cells in PBS were applied by vacuum to Genescreen membranes prewet in $2 \times$ SSC, $10 \%$ (vol/vol) formaldehyde (EM Science, Gibbstown, NJ) on a dot blot minifold (Schleicher \& Schuell, Inc., Keene, NH). The following solutions were sequentially passed through the filter: 100 $\mathrm{ml}$ of $2 \times \mathrm{SSC}, 0.2 \% \mathrm{SDS} ; 100 \mathrm{ml}$ of $2 \times \mathrm{SSC}, 15 \%$ (vol/vol) of formamide (Bethesda Research Laboratories, Gaithersburg, MD) at $60^{\circ} \mathrm{C}$; and $100 \mathrm{ml}$ of $2 \times$ SSC. The membranes were then incubated in $10 \%$ (vol/vol) formaldehyde, $20 \times \mathrm{SSC}$ at $60^{\circ} \mathrm{C}$ for $15 \mathrm{~min}$, followed by two washes $\left(100 \mathrm{ml}\right.$ each) in $2 \times \mathrm{SSC}$, and then baked at $80^{\circ} \mathrm{C}$ for $2 \mathrm{~h}$.

Prehybridization was performed at $42^{\circ} \mathrm{C}$ for $16 \mathrm{~h}$ in $35 \%$ formamide, $1 \times$ Denhardt's, $2 \times$ SSC, $0.5 \%$ SDS, and $50 \mu \mathrm{g} / \mathrm{ml}$ heat-denatured salmon sperm DNA (Sigma Chemical Co.). Hybridization was performed with a ${ }^{32} \mathrm{P}$-labeled cDNA probe for a fragment of RSV F cloned in pUC 9 (16) in the above solution without salmon sperm DNA containing $10 \mathrm{mM}$ EDTA. The probes were labeled by random primer extension (Boehringer Mannheim Biochemicals, Indianapolis, IN) and specific activities exceeded $10^{9} \mathrm{cpm} / \mu \mathrm{g}$ (25). After hybridization, the membranes were washed sequentially in $2 \times$ SSC, $0.5 \%$ SDS $1 \times$ SSC, $0.5 \%$ SDS; and finally, $0.1 \times$ SSC, $0.5 \%$ SDS at $60^{\circ} \mathrm{C}$, dried, and exposed to Kodak XAR-5 film with two intensifying screens at $-70^{\circ} \mathrm{C}$.

Statistical analysis. All values are represented as mean \pm SEM. Comparisons between means were analyzed for statistical significance by paired $t$ test or the Wilcoxon matched-pairs signed rank test, and were considered significant at $P<0.05$.

\section{Results}

Presence of viral F RNA in alveolar macrophages, monocytes, and $C V-1$ cells after $R S V$ exposure. Using a cloned cDNA probe for RSV F RNA, expression of this gene in total RNA extracted from autologous blood and alveolar MP pooled from four donors, and CV-1 cells after exposure of each cell type to RSV for $36 \mathrm{~h}$ at 0 or $3 \mathrm{pfu} / \mathrm{cell}$ was determined. Equivalent amounts of total RNA were subjected to Northern analysis and hybridized with a $\left.{ }^{32} \mathrm{P}\right] \mathrm{cDNA}$ for F RNA (Fig. 1). F RNA was readily detected as a 1.9-kb band in RSV-exposed monocytes (lane 2), alveolar MP (lane 4), or CV-1 cells (lane 6), whereas no detectable F RNA was present in the corresponding cultures not exposed to RSV (lanes 1,3 , and 5) or in CV-1 cells exposed to UV light-inactivated RSV at the same viral dose (lane 7). RNA from monocytes demonstrated a nonspecific hybridization signal that comigrated with the 28 S RNA species and was present at equal intensities in both uninfected and infected cells. Longer exposures of Northern blots also demonstrated hybridization signals of $\sim 17 \mathrm{~kb}$ in size only in lanes exposed to RSV, probably indicating genomic RNA (not shown).

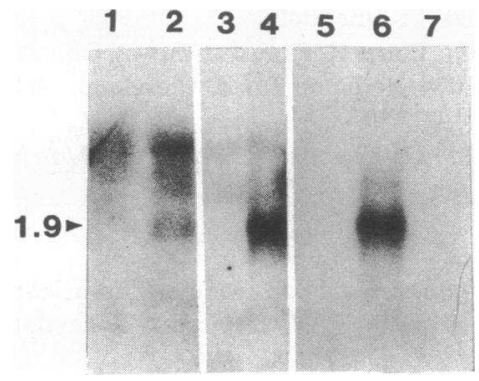

Figure 1. Northern blot analysis of monocyte, alveolar macrophage, and CV-1 RNA. Northern analysis of total RNA, evaluated using a $\left[{ }^{32} \mathrm{P}\right] \mathrm{cDNA}$ probe for RSV F RNA. Lane 1 , monocytes; lane 2, monocytes exposed to RSV; lane 3, alveolar MP; lane 4, alveolar MP exposed to RSV; lane 5 ,

CV-1 cells; lane 6, CV-1 exposed to RSV; lane 7, CV-1 exposed to UV-inactivated RSV. The size of the F RNA was determined using RNA markers (see Methods). Exposure times of the autoradiograms were $12 \mathrm{~h}$ for monocytes, $4 \mathrm{~h}$ for alveolar MP, and $1 \mathrm{~h}$ for CV-1 cells. 
F RNA expression in alveolar and blood MP and RSV protein expression. Expression of RSV F RNA was directly compared at 12 and $24 \mathrm{~h}$ after infection from equal numbers of autologous alveolar and blood MP (each at $5 \times 10^{5}$ cells/ donor, four separate donors). Although expression of F RNA by alveolar and blood MP differed within a given donor (for example, in Fig. 2), no significant differences were seen when the results from four donors were combined. These results suggest that both alveolar and blood MP support RSV transcription and/or replication.

Separate aliquots of RSV exposed cells were analyzed for F protein expression (indirect immunofluorescence) and demonstrated undetectable $\mathrm{F}$ protein after $2 \mathrm{~h}$ exposure to RSV. However, F protein was readily detectable in cells exposed for $24 \mathrm{~h}$ (not shown). Alveolar MP uninfected or infected with RSV and fixed while adherent after $15 \mathrm{~d}$ of culture demonstrated similar morphology containing both rounded and elongated, spindle-shaped cells by phase contrast microscopy (Fig. $3 \mathrm{~A}$ ). Approximately $30 \%$ of the RSV-infected cells continued to express RSV proteins as determined by epi-fluorescent microscopy of the same field, as shown in an example from one donor (Fig. $3 \mathrm{~B}$ ), while uninfected cell cultures did not demonstrate fluorescent staining. Greater than $90 \%$ of the viable cells in culture for $15 \mathrm{~d}$ were capable of ingesting latex particles consistent with an identification as phagocytes.

Productive infection of alveolar macrophages by RSV. Release of new progeny virus from alveolar MP (five donors) after RSV exposure was determined at 2, 6, 24, 48, 72, 96, and 120 $\mathrm{h}$ after exposure to RSV at 0 or $3 \mathrm{pfu} / \mathrm{cell}$. Viral titer in cell-free supernatants and in washed and sonicated adherent cells was determined at each time point. Viral titer in supernatants or disrupted cells declined by $>2$ logs by $6 \mathrm{~h}$ after infection, but then increased by $24 \mathrm{~h}$ after infection and remained elevated through $120 \mathrm{~h}$ (Fig. 4).

The persistence of viral replication was assessed in alveolar MP $\left(5 \times 10^{5}\right.$ cells/time point, five additional donors) after exposure to RSV at 0 or $3 \mathrm{pfu} /$ cell at $6,24,120,240,360,480$, and $600 \mathrm{~h}$ after infection. Medium was changed at each $120-\mathrm{h}$ interval and viral titer determined in cell-free supernatants or disrupted alveolar MP. Alveolar MP contained infectious virus and released virus to the extracellular milieu throughout this period, $600 \mathrm{~h}$ ( $25 \mathrm{~d}$ ) (Fig. 4). Viral titer released from sonicated cells at $6 \mathrm{~h}$ after infection was $198 \pm 115 \mathrm{pfu} / \mathrm{ml}$, which was significantly less than that released at $24 \mathrm{~h}$ after infection,

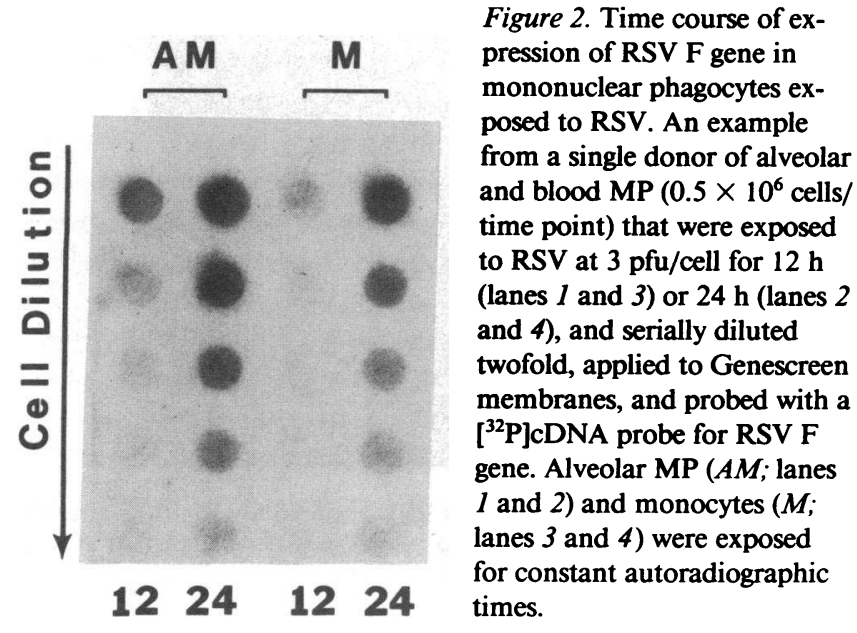

$6,218 \pm 2,211 \mathrm{pfu} / \mathrm{ml}(P<0.01)$. Total virus titer, that present in supernatant plus disrupted cells, at $24 \mathrm{~h}$ after infection was $7,335 \pm 2,416 \mathrm{pfu} / \mathrm{ml}$, which was increased significantly compared with viral titer present in the cultures at $6 \mathrm{~h}$ after infection, $565 \pm 246 \mathrm{pfu} / \mathrm{ml}(P<0.05)$. Taken together, these results indicated that RSV-infected alveolar MP produced new progeny virus.

Alveolar MP from all 10 donors used in these experiments permitted RSV replication. Uninfected alveolar MP cultured in parallel from each donor demonstrated undetectable virus, indicating that the alveolar MP did not harbor virus at the time of bronchoalveolar lavage (not shown). Additionally, RSV exposure of medium-control cultures in the absence of alveolar MP had undetectable viral titers after $24 \mathrm{~h}$ at $37^{\circ} \mathrm{C}$.

Next we examined whether RSV exposure of alveolar MP resulted in cytolytic infection. There were no differences in mean viable cell number of alveolar MP between uninfected and infected cultures at any time point from these donors (Table I). Total virus (supernatant + sonicated cells) produced per infected (immunofluorescent positive), viable alveolar MP was significantly higher at $24 \mathrm{~h}$ after infection than that produced at $120-360 \mathrm{~h}$ after infection $(P<0.05)$. By 480 and 600 $\mathrm{h}$ after infection viral production per cell did not significantly differ from that seen at $24 \mathrm{~h}$ after infection.

\section{Discussion}

Although human monocytes can be productively infected by RSV (26), little is known about the RSV replicative cycle in these cells, nor whether alveolar macrophages differ in their ability to support productive infection. The results presented herein indicate that alveolar macrophages support each stage of RSV replication, resulting in production of infectious virus for prolonged periods.

Northern analysis of RSV-infected blood and alveolar MP and the CV-1 cell line demonstrate the presence of RSV F RNA whose size is consistent with the known size of the transcript for F gene (16). Using this probe, total RSV F RNA accumulation in alveolar MP exceeded that present in blood MP at $36 \mathrm{~h}$ after infection; however, comparable levels of $\mathrm{F}$ RNA were expressed by alveolar and blood MP at 12 and $24 \mathrm{~h}$ after infection. Either differences in the amount or stability of RSV RNA in MP by $36 \mathrm{~h}$ after infection, or differences in the viability of $R S V$-infected MP could account for these results. However, RSV F expression correlated with the time-dependent RSV protein production, indicating that alveolar MP support both transcription and protein expression of RSV genes.

In an earlier study we found that alveolar and blood MP were equally permissive to RSV infection, while cord blood MP were significantly more susceptible to infection with this virus (12). The data presented here on adult blood and alveolar MP confirm and extend these previous observations and demonstrate that alveolar MP cultured in vitro produce infectious virus for prolonged periods after RSV exposure. These combined results indicate that RSV infection and replication in MP may have a role in the extrapulmonary dissemination of RSV and prolonged virus shedding seen in some immunodeficient individuals (27).

Replication of RSV in alveolar MP, a tissue-derived component of the human MP series, extends previous results that demonstrated RSV replication in blood MP and the U937 


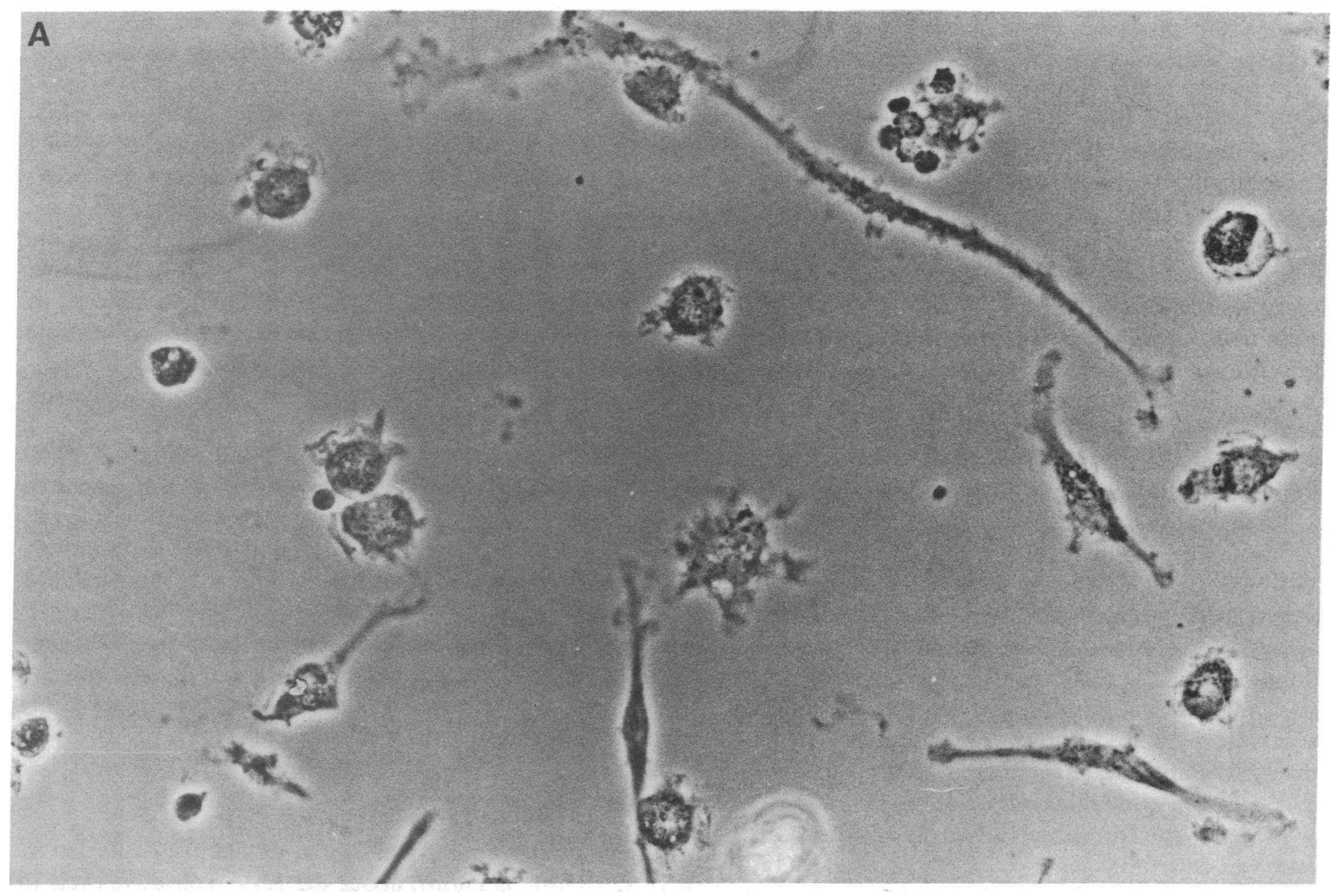

B

Figure 3. RSV protein expression in alveolar macrophages exposed to RSV. A, Phase contrast photograph of RSV-exposed alveolar MP after 15 $\mathrm{d}$ of culture. $B$, Photograph of the same field of cells after immunofluorescent staining with mouse MAb to RSV proteins (FITC-labeled). 


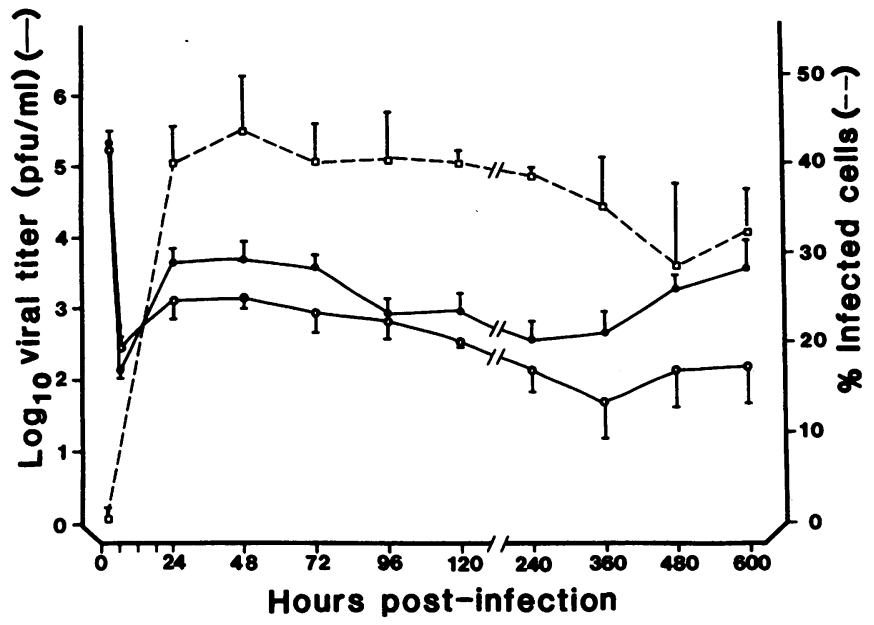

Figure 4. Infection and replication of RSV in alveolar macrophages. The titer of RSV plaque-forming units/milliliter per $10^{6}$ alveolar MP) in supernatants (0) and sonicates (๑) and the percent infection (immunofluorescent cells/total cells) was determined at the indicated hours after infection. Results are mean \pm SEM.

monocytic cell line $(26,28)$. The present results contrast with previous work that demonstrated resistance of bovine alveolar MP to RSV replication, perhaps suggesting species-specific differences in productive $\mathrm{RSV}$ infection of alveolar MP $(29,30)$.

Unexpectedly, RSV-infected alveolar MP showed no alteration in viability compared with uninfected controls. This contrasts with results generally seen in cells infected with RSV, where extensive cytolysis usually occurs by 5-7 d after infection $(1,3)$. MP infected with herpes simplex $(31)$ or Sendai virus (32) (also a member of the paramyxoviruses, as is RSV) have been shown to produce virus for prolonged periods without an apparent effect on MP viability. We find that alveolar MP cultures contain subpopulations of cells capable of replicating or resisting RSV infection for periods up to $600 \mathrm{~h}$ (25 d).

Table I. Viability of Uninfected and RSV-infected Alveolar Macrophages and Production of Virus/Viable Cell with Time after RSV Infection

\begin{tabular}{|c|c|c|c|c|}
\hline \multirow{2}{*}{$\begin{array}{l}\text { Time in } \\
\text { culture }\end{array}$} & \multicolumn{2}{|c|}{ Viable cell number $\left(\times 10^{4}\right)$} & \multirow[b]{2}{*}{ Infected cells } & \multirow{2}{*}{$\begin{array}{l}\text { Virus production } \\
\left(\times 10^{-2}\right)\end{array}$} \\
\hline & Uninfected & Infected & & \\
\hline$h$ & & & $\%$ & pfu/cell \\
\hline 24 & $35.6 \pm 3.1$ & $38.0 \pm 7.0$ & $41.3 \pm 3.2$ & $5.31 \pm 1.37$ \\
\hline 120 & $36.6 \pm 4.3$ & $41.0 \pm 1.7$ & $39.7 \pm 1.6$ & $0.91 \pm 0.41^{*}$ \\
\hline 240 & $32.0 \pm 10.1$ & $35.8 \pm 8.0$ & $38.4 \pm 0.8$ & $0.34 \pm 0.07^{*}$ \\
\hline 360 & $18.4 \pm 2.5$ & $18.6 \pm 2.5$ & $33.2 \pm 5.4$ & $1.16 \pm 0.81^{\ddagger}$ \\
\hline 480 & $13.0 \pm 1.8$ & $12.0 \pm 2.2$ & $28.0 \pm 6.2$ & $7.60 \pm 4.29$ \\
\hline 600 & $9.5 \pm 2.0$ & $9.4 \pm 1.8$ & $31.2 \pm 4.6$ & $17.12 \pm 13.72$ \\
\hline
\end{tabular}

The number of viable cells is the product of the total cells recovered times the percentage that excluded trypan blue. Plaque-forming units per cell was determined from the total viral titer (cells + supernatant) divided by the number of viable, infected cells (\% immunofluorescent) determined at the indicated times. Results are the mean \pm SEM for five donors.

${ }^{*} P<0.01$ vs. $24 \mathrm{~h} ;{ }^{\ddagger} P<0.05$ vs. $24 \mathrm{~h}$.
The factors determining the ability of alveolar MP to resist RSV infection or support replication will require further investigation.

The mechanism(s) by which MP support replication of some virus for prolonged periods ( $>2 \mathrm{wk}$ ), including both DNA and RNA virus (31-37), are only partially understood. Proposed mechanisms include production of noninfectious virions that require homologous infectious virus for replication (defective interfering particles) (38), production of temperature-sensitive viral mutants (39), host cell viral resistance factors, a steady-state situation maintained by equilibrium between infected and uninfected cells (38), failure of the host cell to efficiently cleave viral glycoproteins resulting in reduced viral production, and production of antiviral proteins such as interferon, thus reducing viral production (reviewed in reference 40). Any of these mechanisms could potentially account for the findings of prolonged replication of RSV in alveolar MP cultures; however, in this, and in a previous study (12), syncytial formation has not been observed, suggesting ineffcient cleavage of fusion protein. This may have a role in the prolonged replication of RSV in these cultures. It is also possible that cytokines produced by alveolar MP, including tumor factor, which directly restricts RSV infection of human blood MP (12), have a role in modulating viral replication in alveolar MP (41). Whether these latter observations have a central role in the mechanism of prolonged RSV replication in alveolar MP cultures will require studies at the individual cell level.

Viral production per cell is initially higher in RSV-infected alveolar MP at $24 \mathrm{~h}$ after infection than at 120-360 h after infection. This is probably not due to cell-associated virus, since repetitive washing of RSV-infected alveolar MP does not reduce virus released from disrupted cells. It is possible that the initial RSV replicative cycle in alveolar MP is more efficient than subsequent cycles, which could account for the observed decrease in plaque-forming units per cell. Alternatively, alveolar MP from bronchoalveolar lavage are a heterogeneous population differing in cell density and functional characteristics such as interleukin 1 and $\mathrm{PGE}_{2}$ production $(42,43)$. Viral replication may proceed at varying rates within these subpopulations, but with continued differentiation induced by plastic adherence, an eventual steady-state level of viral production may be seen. At $400-600 \mathrm{~h}$ after infection we observed an increase in plaque-forming units per cell, probably due to release of virus from nonviable cells.

Alveolar macrophages are felt to have a major role in pulmonary defense $(8,44,45)$. Previous authors have demonstrated that RSV infection of monocytes alters the production of interleukin 1 and interferon $(46,47)$. Blood and alveolar MP exhibit important functional differences, including secretion of immunomodulatory and inflammatory mediators $(21$, 48-50), which may have a role in the pathobiology of RSV infections. Each stage of viral replication within MP could potentially alter important biological functions. Precise understanding of the alveolar MP response to RSV infection may require definition of alveolar MP function at these separate stages of RSV replication.

\section{Acknowledgments}

This work was supported by National Institutes of Health SCOR grant HL-37117, PPG HL-25830, GCRC grant M01 RR-0080, Cancer Re- 
search Center grant P30 CA-43073, and an American Lung Association grant (to J. R. Panuska).

The authors acknowledge the excellent technical assistance of $\mathrm{K}$. A Lenner and Jo Ann Nelson.

\section{References}

1. McIntosh, K., and R. M. Chanock. 1985. Respiratory syncytial virus. Virology. 54:1285-1304.

2. Welliver, R. C. 1983. Viral infections and obstructive airway disease in early life. Pediatr. Clin. North Am. 30:819-827.

3. Stott, E. J., and G. Taylor. 1985. Respiratory syncytial virus. Arch. Virol. 84:1-52.

4. Johnson, R. A., G. A. Prince, S. C. Suffin, R. L. Horswood, and R. M. Chanock. 1982. Respiratory syncytial virus infection in cyclophosphamide treated cotton rats. Infect. Immun. 37:369-373.

5. Gardner, S., J. McQuillin, and S. D. M. Court. 1970. Speculation on pathogenesis in death from respiratory syncytial virus infection. $\mathrm{Br}$. Med. J. 1:327-330.

6. Kurlandsky, L. E., G. French, P. M. Webb, and D. D. Porter. 1988. Fatal respiratory syncytial virus pneumonitis in a previously healthy child. Am. Rev. Respir. Dis. 138:468-472.

7. Fishaut, M., J. D. Schwartzman, K. McIntosh, and S. R. Mostow. 1978. Behavior of respiratory syncytial virus in piglet tracheal organ culture. J. Infect. Dis. 138:644-649.

8. Fels, A. O. S., and Z. A. Cohn. 1986. The alveolar macrophage. J. Appl. Physiol. 60:353-369.

9. Mogensen, S. C. 1979. Role of macrophages in natural resistance to virus infections. Microbiol. Rev. 43:1-26.

10. Morahan, P. S., J. R. Connor, and K. R. Leary. 1985. Viruses and the versatile macrophage. Br. Med. Bull. 41:15-21.

11. Brain, J. D. 1988. Lung macrophages: how many kinds are there? What do they do? Am. Rev. Respir. Dis. 137:507-509.

12. Midulla, F., Y. T., Huang, N. Cirino, I. A. Gilbert, E. R. McFadden, and J. R. Panuska. 1989. Respiratory syncytial virus infection of human cord and adult blood monocytes and alveolar macrophages. Am. Rev. Respir. Dis. 140:771-777.

13. Oldstone, M. B. A.1989. Viral persistence (Minireview). Cell. 56:517-520.

14. Belshe, R. B., J. M. Bernstein, and K. N. Dansby. 1984. Respiratory syncytial virus. In Textbook of Human Virology. PSG Publishing Company, Inc., Littleton, MA. 361-381.

15. Pringle, C. R. 1987. Paramyxoviruses and disease. In Molecular Basis of Virus Disease. W. C. Russell et al., editors. Cambridge University Press, Cambridge, UK. 51-90.

16. Collins, P. L., Y. T. Huang, and G. W. Wertz. 1984. Nucleotide sequence of the gene encoding the fusion $(\mathrm{F})$ glycoprotein of human respiratory syncytial virus. Proc. Natl. Acad. Sci. USA. 81:7683-7687.

17. Olmsted, R. A., N. Elango, G. A. Prince, B. R. Murphy, P. R. Johnson, B. Moss, R. M. Chanock, and P. L. Collins. 1986. Expression of the $F$ glycoprotein of respiratory syncytial virus by a recombinant vaccinia virus: comparison of the individual contributions of the $F$ and G glycoproteins to host immunity. Proc. Natl. Acad. Sci. USA. 83:7462-7466.

18. Walsh, E. E., M. W. Brandiss, and J. J. Schlesinger. 1985. Purification and characterization of respiratory syncytial virus fusion protein. J. Gen. Virol. 66:409-415.

19. Merz, D. C., A. Scheid, and P. W. Choppin. 1980. Importance of antibodies to the fusion glycoprotein of paramyxoviruses in the prevention of spread of infection. J. Exp. Med. 151:275-288.

20. Panuska, J. R., K. Fukui, and C. W. Parker. 1988. Initial characterization of products in supernates of human monocytes by 2-dimensional gel electrophoresis: effect of lipopolysaccharide. Biochem. J. 249:501-511.

21. Rich, E. A., J. R. Panuska, R. S. Wallis, C. B. Wolf, and J. J. Ellner. 1989. Dyscoordinate expression of tumor necrosis factor-alpha and interleukin-1 by human blood monocytes and alveolar macrophages. Am. Rev. Respir. Dis. 139:1010-1016.

22. Parks, D. R., V. M. Bryan, V. T. Oi, and L. A. Herzenberg. 1979. Antigen-specific identification and cloning of hybridomas with a fluorescent-activated cell sorter. Proc. Natl. Acad. Sci. USA. 76:19621966.

23. Maniatis, T., E. F. Fritsch, and J. Sambrook. 1982. Molecular Cloning: A Laboratory Manual. Cold Spring Harbor Laboratory, Cold Spring Harbor, NY. 545 pp.

24. Benveniste, P., H. Derry, G. E. Wu, C. J. Paige, and R. G. Miller. 1988. A sensitive dot blot procedure for detecting mRNA in lymphoid cells grown in liquid culture. J. Immunol. Methods. 107:165-177

25. Feinberg, A. P., and B. Vogelstein. 1983. A technique for radiolabelling DNA restriction endonuclease fragments to high specific activity. Anal. Biochem. 132:6-13.

26. Krilov, L. R., R. M. Hendry, E. Godfrey, and K. McIntosh 1987. Respiratory virus infection of peripheral blood monocytes: correlation with aging of cells and interferon production in vitro. J. Gen. Virol. 68:1749-1753.

27. Fishaut, M., D. Tubergen, and K. McIntosh. 1980. Cellular response to respiratory viruses with particular reference to children with disorders of cell-mediated immunity. J. Pediatr. 96:179-186.

28. Gimenez, H. B., H. M. Keir, and P. Cash. 1989. In vitro enhancement of respiratory syncytial virus infection of U937 cells by human sera. J. Gen. Virol. 70:89-96.

29. Toth, T. H., and R. A. Hesse. 1983. Replication of five bovine respiratory viruses in cultured bovine alveolar macrophages. Arch Virol. 75:219-224.

30. Trigo, E., H. D. Liggitt, J. F. Evermann, R. G. Breeze, L. Y. Huston, and R. Silflow. 1985. Effect of in vitro inoculation of bovine respiratory syncytial virus on bovine pulmonary alveolarmacrophage function. Am. J. Vet. Res. 46:1098-1103.

31. Linnavuori, K., and T. Hovi. 1983. Restricted replication of herpes simplex virus in human monocyte cultures: role of interferon. Virology. 130:1-9.

32. Mills, J. 1979. Effects of sendai virus infection on function of cultured mouse alveolar macrophages. Am. Rev. Respir. Dis. 120:1239-1244.

33. Roy, S., L. Fitz-Gibbon, L. Poulin, and M. A. Wainberg. 1988. Infection of human monocytes/macrophages by HIV-1: effect on secretion of IL-1 activity. Immunology. 64:233-239.

34. Brautigam, A. R., F. J. Dutko, L. B. Olding, and M. B. A. Oldstone. 1979. Pathogenesis of murine cytomegalovirus infection: the macrophage as a permissive cell for cytomegalovirus infection, replication and latency. J. Gen. Virol. 44:349-359.

35. Laude, H., B. Charley, and J. Gelfi. 1984. Replication of transmissible gastroenteritis coronavirus (TGEV) in swine alveolar macrophages. J. Gen. Virol. 65:327-332.

36. Peluso, R., A. Haase, L. Stowring, M. Edwards, and P. Ventura. 1985. A trojan horse mechanism for the spread of visna virus in monocytes. Virology. 147:231-236.

37. Isakov, N., M. Feldman, and S. Segal. 1982. Acute infection of mice with lactic dehydrogenase virus (LDV) impairs the antigen-presenting capacity of their macrophages. Cell. Immunol. 66:317-332.

38. Treuhaft, M. W., and M. O. Beem. 1982. Defective interfering particles of respiratory syncytial virus. Infect. Immun. 37:439-444.

39. Pringle, C. R., P. V. Shirodaria, P. Cash, D. J. Chiswell, and P. Malloy. 1978. Initiation and maintenance of persistent infection by respiratory syncytial virus. J. Virol. 28:199-211.

40. Streissle, G. 1981. Persistent viral infections as models for research in virus chemotherapy. Adv. Virus Res. 26:37-61.

41. Midulla, F., Y. T. Huang, I. A. Gilbert, N. M. Cirino, E. A. Rich, and J. R. Panuska. Secretion of prostaglandin $E_{2}$ (PGE2) and tumor necrosis factor (TNF) by human monocytes and alveolar macrophages infected in vitro with respiratory syncytial virus (RSV). Clin. Res. 37:A416. (Abstr.) 
42. Elias, J. A., A. D. Schreiber, K. Gustilo, P. Chien, M. D. Rossman, P. J. Lammie, and R. P. Daniele. 1985. Differential interleukin 1 elaboration by unfractionated and density fractionated human alveolar macrophages and blood monocytes: relationship to cell maturity. J. Immunol. 135:3198-3204.

43. Chandler, D. B., and J. D. Fulmer. 1987. Prostaglandin synthesis and release by subpopulations of rat alveolar macrophages. J. Immunol. 139:893-898.

44. Bernd, K., T. H. Rossing, and J. E. Pennington. 1987. Comparative oxidative microbicidal activity of human blood monocytes and alveolar macrophages and activation by recombinant gamma interferon. Am. Rev. Respir. Dis. 136:266-270.

45. Rich, E. A., D. J. Tweardy, H. Fujiwara, and J. J. Ellner. 1987. Spectrum of immunoregulatory functions and properties of human alveolar macrophages. Am. Rev. Respir. Dis. 136:258-265.

46. Roberts, N. J., A. H. Prill, and T. N. Mann. 1986. Interleukin 1 and interleukin 1 inhibitor production by human macrophages ex- posed to influenza virus or respiratory syncytial virus. J. Exp. Med. 163:511-519.

47. Roberts, N. J. 1982. Different effects of influenza virus, respiratory syncytial virus, and sendai virus on human lymphocytes and macrophages. Infect. Immun. 35:1142-1146.

48. Wewers, M. D., S. I. Rennard, A. J. Hance, P. B. Bitterman, and R. G. Crystal. 1984. Normal human alveolar macrophages obtained by bronchoalveolar lavage have a limited capacity to release interleukin-1. J. Clin. Invest. 74:2208-2218.

49. Martinet, Y., K. Yamauchi, and R. G. Crystal. 1988. Differential expression of the tumor necrosis factor/cachectin gene by blood and lung mononuclear phagocytes. Am. Rev. Respir. Dis. 138:659665 .

50. Jakab, G. J., and G. A. Warr. 1981. Immune-enhanced phagocytic dysfunction in pulmonary macrophages infected with parainfluenza 1 (Sendai) virus. Am. Rev. Respir. Dis. 124:575-581. 